\title{
Julkaise ja tuhoudu?
}

\author{
Erkki Karvonen, Terttu Kortelainen \& Jarmo Saarti (2014): Julkaise tai tuhoudu! \\ Johdatus tieteelliseen viestintään. Vastapaino: Tampere. 240 s. ISBN 978-951-768-425-5
}

"Tutkijan eettinen velvollisuus on pyrkiä lööppeihin", linjaavat Erkki Karvonen, Terttu Kortelainen ja Jarmo Saarti tieteelliseen viestintään johdattelevassa kirjassaan Julkaise tai tuhoudu! Johdatus tieteelliseen viestintä̈n (s. 196). Tutkimustulosten saattaminen julkisuuteen täytyy kuitenkin tehdä menettämättä tutkijan etiikkaa, he tarkentavat.

Vastapainolta ilmestyi muutaman kuukauden sisällä peräti kaksi tieteen tehtäviä ja arviointia sekä tiedeviestintää käsittelevää kirjaa. Julkaise tai tuhoudu ja Tutkimuksen kansallinen tehtävä (Muhonen \& Puuska) ovat syntyneet tarpeesta jäsentää tieteen tekemistä ja tehtäviä uudessa yliopistolaitoksessa. Toisena, konkreettisena pontimena on julkaisufoorumi-hanke eli julkaisujen luokitus neljälle tasolle $(0,1,2,3)$ yhdistettynä yliopistojen uuteen rahoitusmalliin, jossa 13 prosenttia yliopistojen opetus- ja kulttuuriministeriö perusrahoituksesta jaetaan tuotettujen julkaisujen määrän ja luokan perusteella. Julkaisutuotannon merkitys rahoituksen jaossa kasvoi moninkertaiseksi.

Julkaise tai tuhoudu -iskulause on ollut satunnaisesti käytössä jo 1930-luvulla. Elämän ja kuoleman kysymykseksi julkaiseminen on muodostunut vasta nyt, kun sillä on merkittävää vaikutusta yliopistojen rahanjakoon. Tutkimuksen kansallisia tehtäviä taas on syytä analysoida ja pohtia siksi, että suomalaistut- kijoiden tulospaine kohdistuu nimenomaan englanninkieliseen julkaisemiseen.

\section{ORAALISESTA DIGITAALISEEN KULTTUURIIN}

Kirjan kaksi ensimmäistä lukua ovat Karvosen kirjoittamat Tieteen ja tiedeviestinnän historiallinen kehitys sekä Tiede ja tieteellinen viestintä. Ne muodostavat hyvän tiivistyksen tieteellisen kirjoittamisen ja julkaisutoiminnan pitkän aikavälin kehityksestä sekä tiedeviestinnän eri lajeista. Luvuissa kuvataan, kuinka oraalisesta kulttuurista, jossa tietoa välitettiin puhumalla, on siirrytty digitaalisen julkaisemisen aikaan, jolloin uusin tutkimustieto leviää bitteinä maailmanlaajuisesti hetkessä.

Keskiajan kirografisessa kulttuurissa kirjoitukset olivat vielä alisteisia puhekulttuurille. Ne olivat eräänlaisia ääneen puhumisen nuotteja. Kirografisessa kulttuurissa kirjoitusten kopioiminen ja levittäminen oli kirkon monopoli, jonka kirjapainon typografinen kulttuuri mursi. Kirjanpainajat alkoivat julkaista mitä tahansa kaupaksi menevää, eivätkä kirkko ja kruunu pystyneet sensuroimaan kaikkea. 1600-luvulta lähtien tieteelliset seurat ja akatemiat olivat tärkeässä asemassa tieteellisen julkaisutoiminnan kehittämisessä.

Valistuksen aikana tieteellinen ajattelu ja tieteen tekeminen uudistuivat täysin ja tulosten julkaisemi- 
nen vauhdittui. 1700-luvulla luonnontieteiden yhteisö oli jo laajasti omaksunut tieteellisten artikkelien kirjoittamisen aikakauskirjoihin. Vuosisadan lopussa tieteellisiä journaaleja ilmestyi jo lähemmäs 800 . Lehdistön laajeneminen oli osa porvarillisen julkisuuden syntyä.

\section{TIETEELLISISTÄ SEUROISTA}

\section{KUSTANNUSBISNEKSEEN}

Kirjassa käydään lyhyesti läpi tieteellisten seurojen ja akatemioiden sekä tieteellisten lehtien perustaminen. Lehdet saivat alkunsa vuonna 1665 perustetusta Philosophical Transactionsista, joka alkoi julkaista tutkimustuloksia lyhyinä määrämuotoisina teknisinä artikkeleina. Samoihin aikoihin alkoi Pariisissa ilmestyä Journal des scavans, jossa julkaistiin matematiikkaa, luonnonfilosofiaa, historiaan ja teologiaa. Artikkelit alettiin pian myös vertaisarvioida.

Suomen ensimmäinen tieteellinen seura, Societas pro fauna et Flora Fennica, perustettiin Turussa vuonna 1821 . Kymmenen vuotta sen jälkeen sai alkunsa Suomalaisen kirjallisuuden Seura. 1800-luvun lopulla Suomessa toimi yli 30 tieteellistä seuraa, joiden kattojärjestöksi perustettiin Tieteellisten seurain valtuuskunta 1899. Nykyisin siihen kuuluu 260 tieteellistä seuraa. Suomen Kasvatustieteellisellä Seuralla on Kasvatus-lehti ja Aikuiskasvatuksen Tutkimusseuralla Aikuiskasvatus-lehti.

Tiede alkoi ammattimaistua 1800-luvun alun Ranskassa, ja tiedejulkaisemisesta on vähitellen tullut suoranainen teollisuuden haara. Maailman suurin monikansallinen tiedekustantamo Elsevier julkaisee vuosittain noin 2000 tieteellistä julkaisusarjaa, joissa on 250000 tieteellistä artikkelia. Näiden päälle tulee vielä parikymmentätuhatta kirjaa. Elsevierin arkistot sisältävät seitsemän miljoonaa julkaisua, joita ladataan 240 miljoonaa kertaa vuodessa. Kustantamon vuotuinen liikevoitto on miljardi euroa.

Suuret kansainväliset tiedekustantamot tekevät tiliä erityisesti kirjastojen hankinnoilla. Elsevierin tiedetään veloittaneen tieteellisiltä kirjastoilta 20000 dollaria esimerkiksi biokemiaan ja biofysiikkaan erikoistuneen Biochimica et Biophysica Actan vuosikerrasta. Artikkelien kirjoittajat eli varsinaiset sisällöntuottajat tai artikkeleiden arvioijat eli refereet tekevät kustantamoille työnsä ilmaiseksi. Kun vielä kirjastojen hankintoihinsa saama tuki tulee verorahoista, kustantamoiden on aika helppokin nostaa julkaisujensa hintoja. Saavuttamastaan monopoliasemasta käsin kustannustalot ovat onnistuneet nostamaan tieteellisiltä kirjastoilta perittäviä hintoja vuosittain jopa sadalla prosentilla.

\section{VAIHTOEHTOJA JULKAISEMISEEN}

Kirjoittajat arvioivat, että maailmassa on tätä nykyä noin kaksi miljoonaa tieteellistä lehteä. Tieteellisten artikkeleiden kokonaismäärä on noin 50 miljoonaa.

Hirmuvoittoja tahkoavien kustannustalojen vastapainoksi on viime vuosina noussut niin kutsuttuja open access -journaaleja eli vapaan saatavuuden julkaisukanavia. Yksi suomalainen esimerkki on verkossa neljästi vuodessa ilmestyvä Kasvatus \& Aika. Ennen pitkää muutkin tiedelehdet julkaistaan vain sähköisessä muodossa. Kukin voi sitten tulostaa kirjoituksia paperille tarpeidensa mukaan, ellei halua käyttää lukulaitetta.

Julkaisukulujen kattamiseksi on monenlaisia käytäntöjä. Niin sanotuissa kultaisen tien (gold route) julkaisuissa kulut katetaan taustaorganisaation tuella tai kirjoittajamaksuilla. Sisällöntuottajat siis maksavat saadakseen tuottaa lehtiin sisältöä! On paljastunut, että jotkut open access -julkaisut on harkitusti perustettu vain rahastustarkoituksessa. Tutkijoiden pakko julkaista yhä enemmän ja enemmän luo tuottoisia liiketoimintamahdollisuuksia monenlaisille yrittäjille. Varmimmin julkaisumäärän kasvusta hyötyy kustannusbisnes.

On kuitenkin syytä muistaa, ettei verkkolehtien tekeminen tietenkään ilmaista ole. Niiden sisällöt eivät synny yhtään sen vähemmällä työllä kuin paperilehtienkään. Vain painatuskulut jäävät pois. Käsikirjoitusten arvioiminen, artikkeleiden toimittaminen ja taittaminen ovat periaatteessa samanlaista työtä niin paperisessa kuin digitaalisessa formaatissa.

\section{JULKAISUKÄYTÄNNÖT JA KIELIKYSYMYS}

Vuonna 1640 aloitti Suomen ensimmäinen yliopisto Turun akatemia, ja tuohon aikaan pro gradut eli maisterin dissertaatiot kirjoitettiin vielä latinaksi, joskin kreikan ja heprean kielikin sallittiin. Vasta 1850-luvulla opinnäytteen sai laatia ruotsiksi ja suomeksi. Kansainvälisen tieteellisen julkaisemisen kieli 1800-luvun puolivälistä toiseen maailmansotaan asti oli saksa, kunnes englanti nousi sen ohi. 
Turun akatemian aikaan tapana oli, että ohjaava professori kirjoitti tulevan maisterin tutkielman. Esimerkiksi kaunopuheisuuden professori H. G. Porthan (1739-1804) kirjoitti yli sata pro gradua. Opiskelijan tehtävänä oli maksaa opinnäytteen painatuskulut ja puolustaa sitä väitöstilaisuudessa. Käytäntö saattaa tuntua hassulta, mutta nykypäivänä yhä useamman jatko-opiskelijan väitöskirja koostuu tutkimuksen ohjaajan ja tutkimusryhmän kanssa kirjoitetuista yhteisartikkeleista.

Tiedeviestinnän eri muotojen esittely ja tieteenalojen eriytyneet julkaisukäytännöt ovat erityisen ajankohtainen asia Suomessa. Akateeminen toiminta ei ole yksi ja yhtenäinen kokonaisuus, eikä sitä pitäisi myöskään arvioida yhtenä kokonaisuutena, Karvonen ja kumppanit päättelevät.

Kun tutkimuskulttuurit, tutkimusongelmien luonne (esimerkiksi ulottuvuudella universaali-paikallinen) ja julkaisukäytännöt ovat niin erilaiset eri aloilla, miksi on edes yritetty mitata eri tieteenalojen tulosta samoilla mittareilla?

Suomen kaltaisissa maissa julkaisemisen pakolla on oma vivahteensa: arvokasta on ei-suomenkielinen julkaiseminen. Tässä yhteiskunnan (suuri yleisö, kulttuuri, päätöksenteko) ja yksilön (tutkija) intressit vetävät eri suuntiin. Käytännössä tutkijan menestys riippuu englanninkielisten julkaisujen määrästä. Kysymys julkaisemisen kielen yhteiskunnallisesta merkityksellisyydestä kuitenkin vaihtelee aloittain.

Yhteiskuntatieteille ja humanistisille tieteille suomeksi kirjoittaminen suomalaisesta todellisuudesta on toisenlainen tehtävä kuin fyysikolle Suomessa tehdystä fysiikan tutkimuksesta. Tutkimuskohde jo määrittää sitä. Mutta ihmistieteilijän olisi syytä kirjoittaa suomeksi osallistuakseen suomalaista kulttuuria koskevaan keskusteluun. Kieli ei ole vain tiedon siirron tekninen väline, vaan olennainen osa kulttuuria ja sen ylläpitämistä ja kehittämistä. Erityisesti yleistajuinen julkaiseminen on sitä.

Ihmistä, kulttuuria ja yhteiskuntaa koskevan tutkimuksen kielen ei ole hyvä eristäytyä kansallisista kielistä niin, ettei esimerkiksi suomen kielessä olisi vastineita tieteen lingua francassa kehitetyille käsitteille. Teoreettisen käsitteiden "kansallistamisen"kautta tutkimus vasta tulee ymmärretyksi siinä ympäristössä, joka on ollut tutkimuksen kohteena.

\section{YKSILÖSUORITUKSESTA TUTKIMUSRYHMIIN}

Vielä 1950-luvulla pääsääntönä oli yksi kirjoittaja julkaisua kohti. Varsinkin yhteiskuntatieteilijät ja humanistit julkaisevat yhden kirjoittajan monografioita (kirjoja).

Usean kirjoittajan artikkelimuotoinen yhteisjulkaiseminen on ollut tavallista lääketieteessä ja muissakin luonnontieteissä. Lääketieteessä noin 96 prosenttia kansainvälisistä artikkeleista on yhteisjulkaisuja, ja kirjoittajia on (Suomessa) keskimäärin kuusi kussakin artikkelissa. Yhteiskuntatieteissä ja humanistisissa tieteissä kuuden kirjoittajan artikkelit ovat pikemminkin harvinaisuuksia. Yli viidenkymmenen kirjoittajan artikkeleiden määrä on kaksinkertaistunut kymmenen viime vuoden aikana. Vuonna 2011 julkaistiin 140 artikkelia, joissa oli yli tuhat kirjoittajaa.

Kenen kuuluu saada nimensä julkaisun kirjoittajaksi? Ja miten usean kirjoittajan julkaisua painotetaan yliopistojen rahan jaossa? Kirjoittajat kannattavat käytäntöä, jossa eri tieteenalojen erilaiset julkaisukäytännöt pitäisi ottaa huomioon rahoituksen jaossa. Muuten lääke- ja luonnontieteet saavat kohtuutonta hyvitystä humanististen ja yhteiskuntatieteiden kustannuksella vain siksi, että julkaisukäytännöt ovat erilaiset, mutta käytetyt tulosmittarit ovat samat. Se on vähän kuin humanisti juoksisi yksin 800 metriä läketieteen viestijoukkuetta vastaan.

\section{KILPAILUTUKSEN RAKENTEET}

Bourdieulaisittain nähtynä tutkimusten julkaiseminen on tutkijoille eräänlaista peliä akateemisella kentällä. Julkaisuilla tavoitellaan mainetta ja kunniaa, mutta myös virkoja ja muita merkittäviä asemia. Tämä painotus on julkaisemisen historiassa kuitenkin vain yksi vaihe.

Tätä nykyä julkaisemisessa ei ole kysymys vain mainetta ja virkoja hamuavien yksilöiden keskinäisestä kilpailusta. Yhä vahvemmin mahdollisimman runsaaseen julkaisemiseen ajaa pakko. Viime vuoden alusta käyttöön otettu rahoitusmalli lähes kahdeksankertaistaa julkaisujen painoarvon yliopistojen rahoituksen perusteena. Julkaisujen osuus oli aiemmin 1,7 prosenttia yliopistojen opetus- ja kulttuuriministeriöltä saamasta rahoituksesta.

Yliopisto työnantajana on eräänlainen välittävä mekanismi tutkijan/tutkimusryhmän ja opetusministeriön välissä. Opetusministeriö jakaa yliopistoille 
rahaa sen mukaan, miten hyvin ne menestyvät julkaisutuotantokilpailussa. Tuotannon perusteella jaettava rahasumma ei kuitenkaan kasva yliopistolaitoksen tuottaman julkaisumäärän mukaan. Palkitsemisessa on kysymys nollasummapelistä.

Karvonen ja kumppanit valaisevat eri puolilta uusliberalistisen ajan yliopistoelämää ja tutkimustoimintaa, esimerkiksi laadun parantamisen nimissä kiihdytettyä kilpailuttamista seurauksineen sekä kaikkialle tunkeutuvaa arviointia vääristyneine vaikutuksineen. Kilpailuun yhdistyy välineellinen rationaalisuus. Uuden julkisjohtamisen ajattelutavassa toimijoiden toivotaan käyttävän järjestelmän mahdollisuuksia (kannustimia, käytäntöjä ja rakenteita) opportunistisesti hyväkseen. Kun kukin yksilö tavoittelee omaa etuaan (esimerkiksi julkaisemalla mahdollisimman paljon menestyäkseen virkakilpailussa), tuottavuus kasvaa ja laatu paranee.

Ja halutaanpa tai ei, julkaisuluokittelua tullaan käyttämään paitsi yliopistojen, tiedekuntien ja laitosten, myös yksilöiden arvioimiseen ja rankkaamiseen. Virkoja täytettäessä yksilöiden ansioita tietenkin pisteytetään sen mukaan, kuinka paljon kullakin on kolmostason, kakkostason ja ykköstason julkaisuja. Paljon kolmos- ja kakkostason julkaisuja tuottavia halutaan rekrytoida, koska he hankkivat yliopistolle enemmän ministeriön rahoitusta kuin muut. Kun rahoitusmallilla kannustetaan tuottamaan "nopeammin, enemmän, halvemmalla" julkaisua kohti laskettu palkkiosumma pienenee koko ajan. Mitä enemmän koko yliopistolaitos tuottaa, sitä enemmän kunkin yksittäisen yliopiston täytyy tuottaa sälyttääkseen aiemman osuutensa julkaisujen perusteella jaettavasta rahoituksesta.

Heikki Hellman ja Eija Poteri ovat Media \& viestintä -lehdessä (2012) laskeneet, että kun vuonna 2010 yliopistot julkaisivat noin 19000 vertaisarvioitua kansainvälistä artikkelia tai monografiaa ja kun yliopistojen perusrahoitus oli 1,7 miljardia euroa, yhden kansainvälisen artikkelin laskennalliseksi arvoksi saadaan noin 8000 euroa. Vastaavasti kotimaisessa aikakauslehdessä julkaistun artikkelin arvoksi saadaan 6800 euroa.

\section{AKATEEMISEN KAPITALISMIN KIROT}

Se, että yliopistojen rahoitus on kytketty tiiviisti julkaisujen tuottamiseen, muuttaa "akateemisen elä- män ekosysteemiä" markkinatalouden suuntaan (s. 13). Yksi tapa tiivistää tieteellisen toiminnan historia on kuvata se eräänlaisena "tahriintumisen kertomuksena". Tiede on ollut luonteeltaan lahjataloutta, mutta siihen on sekoittunut yhä enemmän markkinatalouden piirteitä. Vapaa, idealistiseen tietämisen haluun perustunut tiede tahriintuu kaupallisiin kytkentöihin sitoutuessaan.

Markkinatalouden logiikkaa noudattavat periaatteet ja käytännöt kolonisoivat siirtomaaisännän tavoin akateemista maailmaa, joka näin menettää entistä autonomiaansa. Yrityksistä ja yliopistoista tulee yritysten kaltaisia, jotka tuottavat sitä, mitä maksavat tahot markkinamekanismien välittämänä niiltä tilaavat. Yliopistotutkimuksen luonne muuttuu, kun valtio, yliopisto ja yritykset muodostavat kokonaisuuden, jossa rajat hämärtyvät.

Hybridiyliopiston tutkijat joutuvat käyttämään kuonokoppaa, jotteivät tulisi viestineensä julkisuuteen mitään sellaista, joka voi olla yritysten etujen kannalta haitallista (Suomessa esimerkiksi tapaus VTT vuonna 2010). Yliopistoihin yritysmaailmasta omaksuttu uusi hallintojohtaminen on vallannut alaa yliopistojen sisäiseen kollegiaaliseen demokratiaan perustuneelta hallintotavalta.

Uuden julkisjohtamisen oppi perustuu ajatukseen, että yksityiset markkinat käyvät malliksi kaikille yhteiskuntaelämän alueille. Uusi yliopistokulttuuri mahdollisesti suosii pelurihenkistä ihmistyyppiä. Kirsi-Mari Kallion (2014) tutkimuksen mukaan yliopistojen henkilökunta vastustaa suoritusmittausten mukanaan tuomia negatiivisiksi kokemiaan ilmiöitä, kuten tulostehtailua vääristyneitä mittareita varten, suuntautumista riskittömään nollatutkimukseen.

Kirjassa käydään läpi myös paljon huomiota saavat kansainväliset yliopistoarvioinnit ja niiden kritiikki. Maineeseen ja houkuttelevuuteen vaikuttavat vertailut ovat jo saaneet yliopistot mukautumaan käytettyihin mittareihin ja muokkaamaan toimintaan mittareiden mukaisiksi. Mittarit voivat alkaa ohjata toimintaa tieteen itsensä kannalta epätarkoituksenmukaiseen suuntaan. Ministeriön laskentamallilla on "todellisuutta rakentava luonne", kirjoittajat kumppanit toteavat (s. 14).

Tutkimuksen ja julkaisujen arviointitapoja ja niiden taustoja esitellään verraten yksityiskohtaisesti. Kirjoittajat purkavat myös sitä, miten internetissä 
voidaan arvioida tutkimuksen ja tutkijoiden näkyvyyttä ja vaikuttavuutta laajemmin.

Uuteen kulttuuriin kuuluu myös, että yliopistojen rehtoreista on tullut alaisiaan käskyttäviä toimitusjohtajia. Valtaa käytetään keskusjohtoisesti ylhäältä alaspäin. Yliopistoista on tullut osa tieto- ja innovaatioteollisuutta. Yliopistotyönantaja kuuluu Elinkeinoelämän keskusliittoon, jolta taas oppii kaiken tarpeellisen kilpailukyvyn retoriikasta. Sivistyksen ja valistuksen suuri kertomus yliopistojen legitimaatioperustana on vaihtunut talouden imperatiiviin, tuloksellisuuteen ja esimerkiksi rahassa mitattaviin innovaatioihin ja tuotteisiin.

\section{JULKAISE JA TUHOUDU}

Pitääkö julkaisemisen tahtia jatkuvasti nopeuttaa? Vai pitäisikö tutkijoille antaa enemmän työrauhaa tehdä huolella hyvää tutkimusta? Kirjoittajat pohtivat näitä kysymyksiä, mutta oikeastaan vastaus siihen löytyy rahoitusmallista. Se kannustaa julkaisemaan entistä enemmän, ja julkaisujen tasoluokitus saa huolehtia laadusta.

Toinen asia sitten on, suostuvatko yliopistotutkijat jatkuvasti kiristämään työtahtia ja lisäämään palkattoman työn määrää päästäkseen entistä suurempiin tuotantolukuihin. Ja vaikka tutkijat (tietysti?) suostuvatkin tekemään entistä enemmän, jossain vaiheessa saattaa tulla vastaan inhimillisen kestokyvyn rajat. "Työtahdin jatkuvaa kiristämistä ei kestä tutkijankaan terveys", ironisoivat kirjoittajat loppuluvussa, ja neuvovat julkaisuvaatimusten ja työtahdin hidastamista. Kohtuullisuuden, terveyden ja laadun nimissä.

Maailmalla puhutaan käsitteillä "slow scholarship" ja "slow science". Ehkä seuraava teknologinen murros automatisoi hallintotehtävät luoden mahdollisuuksia ja resursseja rauhallisemmalle tieteelle ja syventymiselle.

\section{ANALYYSIA JA OHJEITA}

Nyt kun tutkimuksia ja tieteellisiä tekstejä on saatavilla vaivatta lähes rajaton määrä, tiedeviestinnästä pitäisi oppia perustiedot kaikilla koulutusaloilla. Yhä useampi joutuu työssään viestimään, ja vielä useampi joutuu kauhomaan ja arvioimaan tutkimuksia ja tekstejä sekä seulomaan niistä luotettavan tiedon omiin tarpeisiin. Tutkimusviestintä tapahtuu "semanttisessa ekosysteemissä", jossa menestyminen edellyttää omanlaisiaan taitoja, erityisesti yleisöjen mukaan sovitettuja viestintätapoja. Se edellyttää myös systeemin toimintatapojen tuntemusta.

Vaikkei samaa artikkelia tulekaan julkaista yhtä aikaa useissa lehdissä, tehokkaaseen tutkimusviestintään ja tutkijan maineenhallintaan kuuluu tulosten julkaiseminen muokattuna eri foorumeilla, tähdentävät kirjoittavat. Joukkoviestimissä esitellään tutkimusta ja tuloksia suurelle yleisölle, konferensseissa tutkijayhteisöille, oppikirjoissa opiskelijoille. Monilla aloilla tärkeitä foorumeita ovat myös ammatilliset julkaisut, joiden kautta tulokset viestitään tehokkaasti alan käytännön toimijoille.

Kirjaan sisältyy myös aivan konkreettisia ohjeita, miten käsikirjoituksen etenemistä julkaisuksi voi edistää. Samalla käsitellään myös entistä tärkeämmiksi käyneet tekijänoikeus- ja muut sopimusasiat. Tieteellisten artikkelien julkaiseminen on siitä erikoinen tuotannon ala, että työntekijät luovuttavat työnsä tulokset ilmaiseksi yrityksille ja ostavat nämä sitten takaisin käyttöönsä joko suoraan tai välittäjien, kuten tieteellisten kirjastojen kautta.

Kirjoittavat sanovat tekevänsä aikalaisdiagnoosia eli tutkivansa nykyajan itsestään selvinä otettuja ajattelu- ja toimintatapoja, ajan henkeä. Kirjoittajat onnistuvat valottamaan tieteellisen julkaisutoiminnan näkymättömäksi jääneitä ilmiöitä ja nykyistä arvioinnin ongelmallisuutta. Kirja on verraten moniaineksinen ja sisältää keskenään ehkä hiukan epäsuhtaista materiaalia. Yhtältä siinä on vahvaa ja ajankohtaista (ja ajatonta) yliopisto- ja tiedepoliittista keskustelua ja toisaalta aika yksityiskohtaista erittelyä julkaisuprosessista. Sitä voi myös pitää aiheen laaja-alaisena ja monipuolisena käsittelynä. Kirjaa voi kehua selkeydestä ja lukijaystävällisyydestä.

Kirjan alussa oleva kahden ensimmäisen luvun, noin 70 sivun, verran pitäisi kaikkien yliopisto-opiskelijoiden alasta riippumatta oppia tästä yliopiston yhdestä perustehtävästä. Ne, jotka tuntevat kutsumusta tutkijan uralle tai muuten tiedeviestintään, lukevat koko kirjan. Kirjan pitäisi kuulua ainakin kaikkien tutkijakoulujen opintovaatimuksiin.

Heikki Silvennoinen kasvatustieteen professori Turun yliopisto 